\author{
Asian Development Policy Review \\ $\operatorname{ISSN}(e):$ 2313-8343 \\ $\operatorname{ISSN}(p): 2518-2544$ \\ DOI: 10.18488/journal.107.2021.94.209.219 \\ Vol. 9, No. 4, 209-219. \\ (C) 2021 AESS Publications. All Rights Reserved. \\ URL: www.aessweb.com
}

\title{
EXPORTS OF SERVICES, OUTPUT AND PRODUCTIVITY GROWTH IN EUROPE
}

Maja Bacovic

\author{
Associate Professor at the Faculty of Economics, University of Montenegro, \\ Montenegro. \\ Email:majab@ucg.ac.me Tel:o038220241138
}

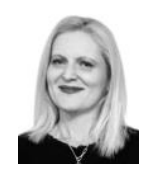

Article History

Received: 12 August 2021 Revised: 6 September 2021 Accepted: 27 September 2021 Published: 18 October 2021

\section{Keywords}

Exports of goods

Exports of services

Economic growth

Productivity

Knowledge-intensive services Output.

JEL Classification: $\mathrm{F} 14 ; \mathrm{O} 47$.

\section{ABSTRACT}

In this study, we analyse the impact of service exports on GDP and productivity growth in a sample of thirty-eight European countries for the period 2000-2019. Descriptive statistics analysis of the panel data shows that growth in exports of goods is more positively related to GDP growth, total fixed assets growth and productivity growth, while growth in export of services is more positively related to employment growth. In addition, the analysis shows that the volume of exports (in terms of its share in relation to GDP) of knowledge-intensive services (information and communication, other business services, intellectual property) is higher in more developed countries (measured as GDP per person). The pooled panel OLS model (fixed effects) with GDP growth rate and labour productivity growth as the dependent variables shows a positive impact on GDP growth of exports of services, although the positive impact of growth in exports of goods is higher. It applies to labour productivity growth, with a larger positive impact from exports of goods than services.

Contribution/ Originality: This study contributes to the literature as presents the estimation of the impact of exports of services on GDP and productivity growth using the most recent data for European countries over the last two decades.

\section{INTRODUCTION}

Export expansion is often seen as an important determinant of output growth. This is particularly relevant for countries with limited or small local markets, as pointed out by Herzer, Nowak-Lehmann, and Siliverstovs (2006). In addition, as the export of goods and services is an important component of aggregate demand, its growth may support GDP growth. As pointed out by Riezman, Whiteman, and Summers (1996) exports provide inflow of foreign currency, which could further be used to finance investments.

Empirical evidence shows that the contribution off all exports to income growth is not linear. In economies in which export of goods dominates, higher economic growth rates are observed (Kalaitzi \& Cleeve, 2018). Gabriele (2006) points out that services exports are a positive determinant of economic growth in the long run, but the effect is weaker in developing countries than in developed countries.

International trade in services at the global level has risen significantly over the last two decades, much faster than that of non-service activities (Pain \& Welsum, 2005). The same applies to Europe. While both exports of goods and services have grown in most European countries during the last two decades, the growth of services 
exports was higher. We analysed the exports of goods and services for 38 European countries from 2000 to $2019^{1}$, and observed that the average share of exports of goods in GDP in all countries increased from $29 \%$ in 2000 to $36.3 \%$ in 2019 . The export of services as a percentage of GDP increased from $11.8 \%$ to $25.6 \%$. In the same period, the average annual growth in the export of services was $6.8 \%$, while the average growth of goods exports per GDP was $5.7 \%$.

In eight countries from the sample ${ }^{2}$ share of services exports represent more than $50 \%$ of total exports, while in nine countries exports of services are significant (participation in total export from 30-50\%) ${ }^{3}$. In the remaining 21 countries, service exports represent less than $30 \%$ of total exports ${ }^{4}$.

The empirical analysis in this study (panel data) shows that, while exports of services as share in GDP has grown, both average labour productivity growth and TFP growth declined over the last two decades in Europe Figure 1. As productivity growth is commonly seen as a source of economic growth in the long run, it is relevant to investigate the role of expansion of the services sector and its export.

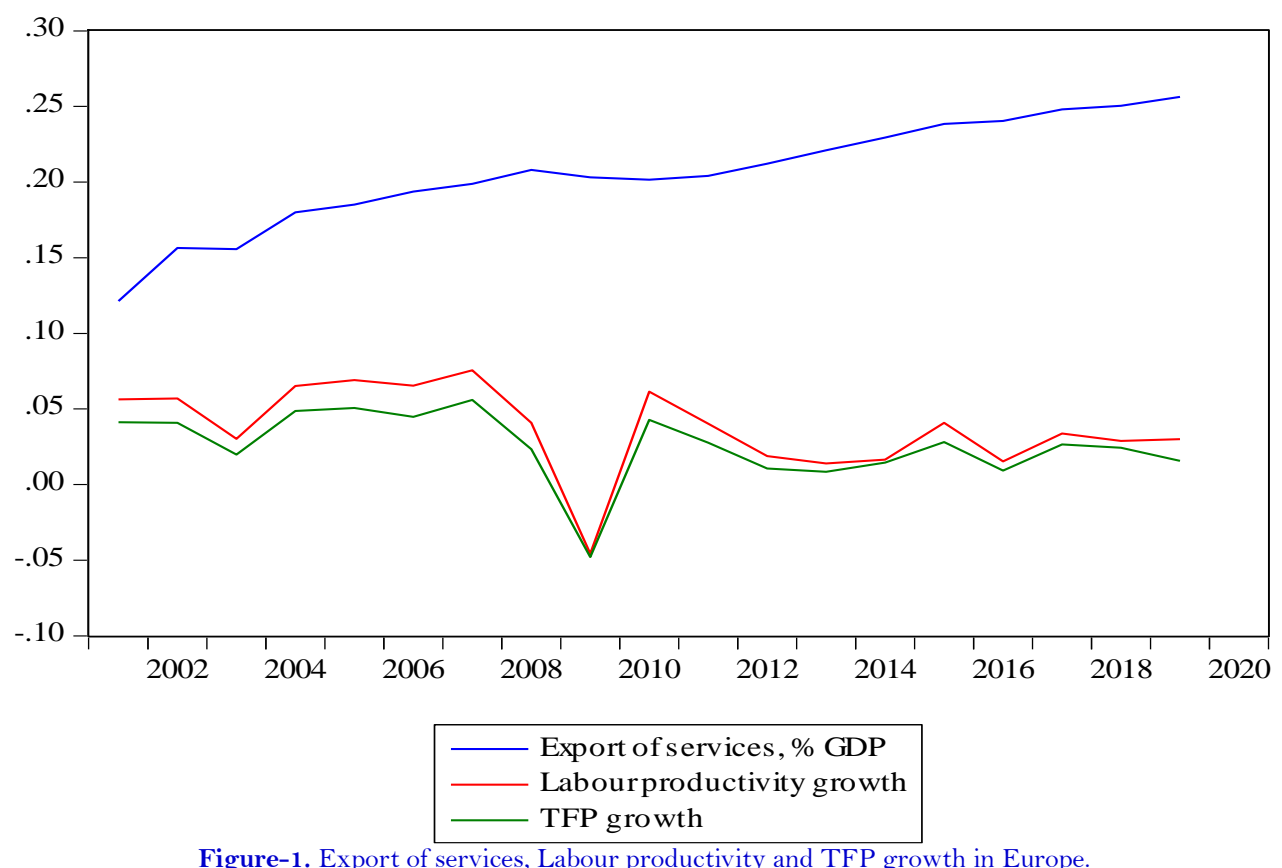

Figure-1. Export of services, Labour productivity and TFP growth in Europe.

The aim of this study is to examine the relationship between revenue from export of services, GDP and labour productivity growth. We investigate the significance of export of services for GDP and productivity growth in European countries, using a panel polled OLS model with fixed effects. A descriptive statistics analysis of panel data was also applied. For descriptive statistics analysis, services exports were disaggregated following BPM6 standards into the following sectors: manufacturing services on physical inputs owned by others; maintenance and repair services; transport; travel; construction; insurance and pension services; financial services; charges for the use of intellectual property; telecommunications, computer, and information services; other business services; personal, cultural, and recreational services and government goods and services.

\footnotetext{
${ }^{1}$ Upon data availability. Although for most countries from the sample data were available for entire period, for several were not, but as long as we had data for at least six consecutive years (which are the latest), we decided to include them in the sample.

${ }^{2}$ Greece, Croatia, Cyprus, Luxemburg, Malta, Montenegro, Albania and Kosovo

${ }^{3}$ Denmark, Estonia, Ireland, Spain, Latvia, Portugal, Romania, Iceland, United Kingdom

${ }^{4}$ Belgium, Bulgaria, Czech republic, Germany, France, Italy, Lithuania, Hungary, Netherlands, Austria, Poland, Slovenia, Slovakia, Finland, Sweden, Norway, Switzerland, North Macedonia, Serbia, Turkey, Bosnia and Hercegovina
} 
This study has six sections. The first section is the introduction, followed by a literature review. The third section provides a detailed overview of the expansion of services exports in Europe. The research methodology and empirical results are presented in the fourth section. The discussion and conclusions of the research are presented in the fifth and sixth sections of the study.

\section{LITERATURE REVIEW}

As research interest in this topic has expanded, the availability of research on services is plentiful. We list only selected sources that were found to be the most relevant for this study. Schwarzer (2017) investigated the impact of exports on firm's productivity in Germany and found that in exporting firms productivity is higher than in firms oriented to the domestic market, but also that variations among economic sectors exist. Dincer and Tekin-Koru (2017) show that the productivity of exporting firms in Turkey is higher than that of non-exporting firms. Malchow-Møller, Munch, and Skaksen (2015) reached a similar conclusion but found that in services the impact of exports on productivity is weaker. Schwarzer (2017) found that the propensity to export is significantly lower in the service sector than in the manufacturing sector. Chen and Tang (1990) in their study on the impact of exports on productivity growth in Taiwan, found that exports contribute to productivity growth, through the economies of scale. Study by Sorbe, Gal, and Millot (2018) shows that productivity is weaker in services sector, but suggest innovations and new technologies as an answer. Cattaneo, Engman, Saez, and Stern (2010) found that services sector is important for GDP growth, but suggested sectoral approach in its analysis. Gabriele (2006) shows that the positive impact of services on GDP growth is stronger in developed then in developing countries. Sandri, Alshyab, and Ghazo (2016) shows that trade in services positively affect economic performance in Jordan. Francois and Hoekman (2010) found that the services sectors have a positive impact on the overall competitiveness of the country. Bacovic, Jacimovic, and Cerovic Smolovic (2020) found that an export of travel services is strong determinant of GDP growth in the short run, while in the long run its impact is less significant. In their study of UK plants, Harris and Moffat (2015) found that productivity is higher in plants which export and import goods and services, although the results are stronger in the manufacturing sector than in the services sector. Minondo (2014) found that productivity in Spain is higher in companies that export services than in those that don't. Manghnani (2020) presented similar results for Indian companies. Chuang (1998) points out that importing capital goods from more technologically advanced economies may influence productivity growth. Bacovic (2021) studied TFP growth applying a sectoral approach and found it to be higher in goods sectors than in the services sector. Similar results were obtained by Foster-McGregor and Verspagen (2017).

Mishra, Lundstrom, and Anand (2011) stressed the growing importance of the services sectors in terms of its impact on export growth. Kordalska and Olczyk (2018) found that the services are major engines of growth in EU15 countries, but of lower relevance for New Member States and accession countries. Krenz (2014) and Chala (2015) investigated specialization in export of services. As in this study we investigate the impact of exports of services on labour productivity and TFP growth, we found many sources in the literature confirming the high relevance of the productivity growth for output growth (Barro, 1998; Comin, 2010; Dombi, 2013; Nelson, 2000).

\section{EXPORTS OF SERVICES IN EUROPE}

The international trade data's descriptive statistics analysis on the sample of thirty-eight European countries and the period from 2000 to 2019 shows that both exports of goods and exports of services have grown in Europe, leading to corrections of the current account disequilibrium (panel mean). Exports of services have grown by higher rate, with its share in GDP growing from $11.8 \%$ in 2000 to $25.6 \%$ in 2019. In the same period, exports of goods' share in GDP increased from $29 \%$ to $35.8 \%$. The current account balance (\% of GDP) transitioned from deficit twenty years ago to the surplus fifteen years later. GDP growth rates were reduced, from average 9 percentages to 4.6 percentages in 2019 Table 1 . 
Table-1. Indicators of international trade, current account balance and GDP growth in Europe, 2000-2019.

\begin{tabular}{c|c|c|c|c}
\hline & $\begin{array}{c}\text { Export of goods, \% } \\
\text { GDP }\end{array}$ & $\begin{array}{c}\text { Export of services, } \\
\text { \% GDP }\end{array}$ & $\begin{array}{c}\text { Current Account balance, \% } \\
\text { GDP }\end{array}$ & $\begin{array}{c}\text { GDP } \\
\text { growth }\end{array}$ \\
\hline 2000 & $29.0 \%$ & $11.8 \%$ & $-2.8 \%$ & \\
\hline 2005 & $34.0 \%$ & $18.5 \%$ & $-3.3 \%$ & $9.0 \%$ \\
\hline 2010 & $35.0 \%$ & $20.2 \%$ & $-1.4 \%$ & $4.9 \%$ \\
\hline 2015 & $35.8 \%$ & $23.8 \%$ & $0.6 \%$ & $5.3 \%$ \\
\hline 2019 & $36.3 \%$ & $25.6 \%$ & $0.2 \%$ & $4.6 \%$ \\
\hline Obs & 630 & 630 & 612 & 708 \\
\hline${\text { Source: } \text { Eurostat data }^{5}}$ & & & \\
\hline
\end{tabular}

Source: Eurostat data

From the exports of services, the most significant increase in terms of share in GDP was observed in exports of financial services, transport, information and communication services and other business services, while share in GDP of the manufacturing services on physical inputs owned by others declined (Table 2). Following classification of services presented by Amil, Giannoplidis, and Lipp-Lingua (2007) the fastest growing service sectors are the knowledge-intensive. The authors also reported that the knowledge-intensive services generated more employment and turnover within members of European Union from 1990 to 2006.

Table-2. Export of services, \% of GDP.

\begin{tabular}{|c|c|c|c|c|c|c|c|c|c|c|c|c|}
\hline & 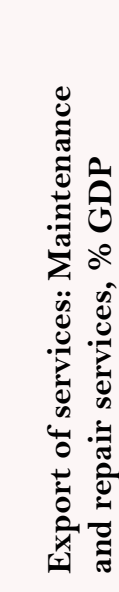 & 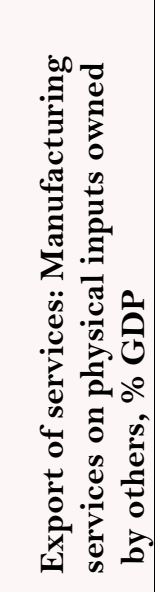 & 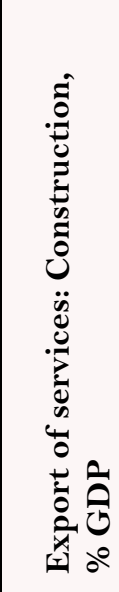 & 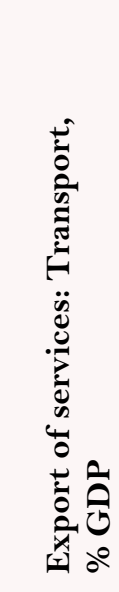 & 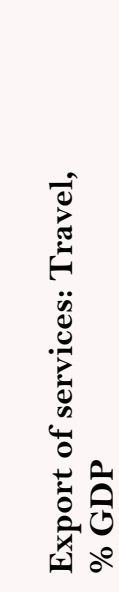 & 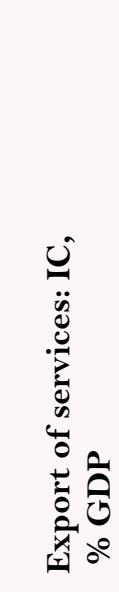 & 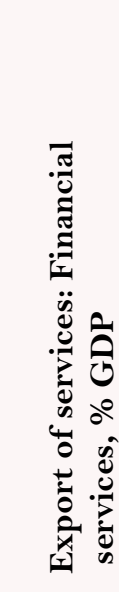 & 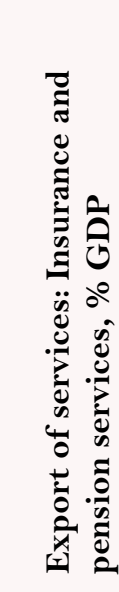 & 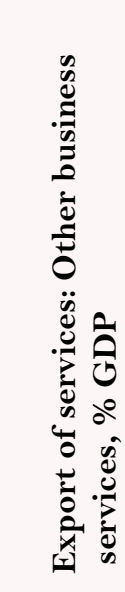 & 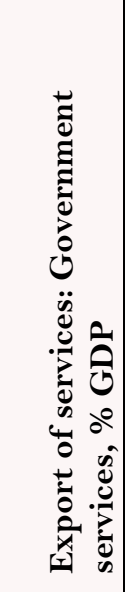 & 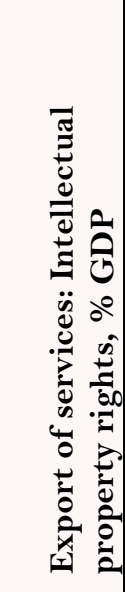 & 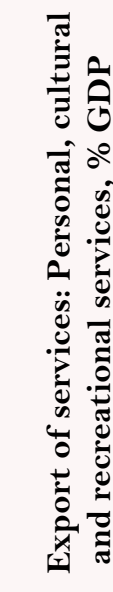 \\
\hline 2000 & 0.08 & 1.49 & 0.19 & 1.36 & 3.90 & 0.38 & 0.44 & 0.10 & 1.34 & 0.09 & 0.18 & 0.14 \\
\hline 2005 & 0.23 & 0.69 & 0.22 & 3.05 & 4.11 & 1.17 & 6.22 & 0.57 & 2.37 & 0.14 & 0.43 & 0.51 \\
\hline 2010 & 0.15 & 0.52 & 0.31 & 3.87 & 4.06 & 1.75 & 4.53 & 0.50 & 2.93 & 0.19 & 0.95 & 0.91 \\
\hline 2015 & 0.20 & 0.69 & 0.40 & 4.26 & 5.49 & 2.00 & 4.45 & 0.44 & 3.98 & 0.16 & 0.78 & 1.37 \\
\hline 2019 & 0.27 & 0.58 & 0.38 & 4.59 & 5.94 & 2.81 & 3.77 & 0.41 & 4.66 & 0.14 & 0.84 & 1.35 \\
\hline obs & 497 & 506 & 516 & 528 & 5411 & 524 & 528 & 528 & 516 & 509 & 518 & 501 \\
\hline
\end{tabular}

Source: Eurostat data ${ }^{6}$

Exports of services represents significant source of the foreign exchange for both developed and developing economies. Analysis on Eurostat's 2018 data on international trade data shows that exports of specific services (travel) represents almost half of the total exports of services in some European countries. Export of travel represents more than $40 \%$ of total export of services in six high-income European countries (Greece, Spain, Croatia, Italy, Portugal, Iceland) and five middle-income countries (Montenegro, Albania, Turkey, Bulgaria, Kosovo). Transportation services represents more than $30 \%$ of total exports of services in fifteen European countries, while exports of other business services represents more than 20\% in fourteen European countries (e.g. France, Italy,

${ }^{5}$ Balance of payments by country - annual data (BPM6) [bop_c6_a $]$, GDP and main components (output, expenditure and income) [nama_10_gdp], extracted on February 25, 2021

${ }^{6}$ Balance of payments by country - annual data (BPM6) [bop_c6_a], extracted on February 25, 2021. 
Malta, United Kingdom, Ireland, Belgium, Germany, Austria, etc.). The charges for intellectual property represents more than $10 \%$ of export of services in three European countries (Netherlands, Finland, Switzerland), while in the other six represents 5-10\% of export od services (France, Germany, Ireland, Hungary, Sweden, United Kingdom). ICT services are relevant exports component high number of countries (in 16 European countries represents more than $10 \%$ of total exports of services).

Further analysis shows that larger share of exports of knowledge-intensive services sectors (transport, information and communications, financial services, other business services, intellectual property rights) corresponds to higher GDP per capita (Table 3).

Table-3. Classification of exports (\% GDP) based on GDP per capita (average 2000-2019).

\begin{tabular}{|c|c|c|c|c|c|}
\hline & \multicolumn{5}{|c|}{ GDP per capita (euro) } \\
\hline & {$[0,20000]$} & $\begin{array}{l}{[20000,} \\
40000]\end{array}$ & $\begin{array}{l}{[40000,} \\
60000]\end{array}$ & $\begin{array}{l}{[60000,} \\
80000]\end{array}$ & All \\
\hline Export of goods, \% GDP & $38.0 \%$ & $31.0 \%$ & $39.0 \%$ & $40.0 \%$ & $36.0 \%$ \\
\hline \% Observations & $50.0 \%$ & $37.0 \%$ & $10.0 \%$ & $4.0 \%$ & \\
\hline Export of services, \% GDP & $18.0 \%$ & $17.0 \%$ & $20.0 \%$ & $21.0 \%$ & $18.0 \%$ \\
\hline$\%$ Observations & $50.0 \%$ & $37.0 \%$ & $19.0 \%$ & $4.0 \%$ & \\
\hline Construction, \% GDP & $0.0 \%$ & $0.0 \%$ & $1.0 \%$ & $0.0 \%$ & $0.0 \%$ \\
\hline$\%$ Observations & $51.0 \%$ & $36.0 \%$ & $11.0 \%$ & $2.0 \%$ & \\
\hline Travel, \% GDP & $6.0 \%$ & $3.0 \%$ & $2.0 \%$ & $4.0 \%$ & $4.0 \%$ \\
\hline$\%$ Observations & $49.0 \%$ & $36.0 \%$ & $11.0 \%$ & $3.0 \%$ & \\
\hline Transport, \% GDP & $4.0 \%$ & $3.0 \%$ & $5.0 \%$ & $3.0 \%$ & $4.0 \%$ \\
\hline$\%$ Observations & $50.0 \%$ & $36.0 \%$ & $11.0 \%$ & $3.0 \%$ & \\
\hline $\mathrm{IC}, \% \mathrm{GDP}$ & $1.0 \%$ & $2.0 \%$ & $3.0 \%$ & $6.0 \%$ & $2.0 \%$ \\
\hline$\%$ Observations & $50.0 \%$ & $35.0 \%$ & $11.0 \%$ & $4.0 \%$ & \\
\hline Finance, \% GDP & $2.0 \%$ & $3.0 \%$ & $1.0 \%$ & $3.0 \%$ & $2.0 \%$ \\
\hline$\%$ Observations & $50.0 \%$ & $36.0 \%$ & $11.0 \%$ & $3.0 \%$ & \\
\hline Other business services, \% GDP & $3.0 \%$ & $4.0 \%$ & $4.0 \%$ & $6.0 \%$ & $3.0 \%$ \\
\hline$\%$ Observations & $5.0 \%$ & $4.0 \%$ & $1.0 \%$ & $0.0 \%$ & \\
\hline Intellectual property, \% GDP & $0.0 \%$ & $1.0 \%$ & $1.0 \%$ & $3.0 \%$ & $1.0 \%$ \\
\hline$\%$ Observations & $51.0 \%$ & $34.0 \%$ & $11.0 \%$ & $4.0 \%$ & \\
\hline
\end{tabular}

Descriptive statistics analysis on panel data shows that growth in exports of goods is more significantly positively associated with GDP growth compared to growth in exports of services (Table 4). Furthermore, descriptive statistics analysis shows that growth in exports of goods has stronger positive impact to total factor productivity growth (TFP) 7 than exports of services growth. This is similar to findings presented by Moro (2015) who found that growth in services has negative effect on TFP and GDP growth. Similar findings apply for exports' impact to the labour productivity ${ }^{8}$ growth, with stronger positive relation between exports of goods growth and labour productivity growth that exports of services growth, respectively. Opposite to TFP growth, growth in exports of services has stronger impact to the employment growth than growth in exports of goods. Similar findings can be found in literature, as services sector growth is more employment growth driven, while industry (manufacturing) is more productivity growth driven. Growth in exports of goods has stronger impact to the total fixed assets growth than growth in exports of goods.

\footnotetext{
${ }^{7}$ Total factor productivity was estimated by author, applying growth accounting approach. Detailed results are available on request, while methodology can be found in Bacovic (2021)

${ }^{8}$ Output per person employed, author's estimates based on Eurostat and ILO data
} 


\begin{tabular}{|c|c|c|c|c|c|c|c|c|}
\hline & 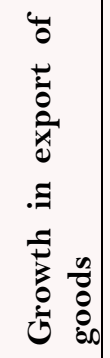 & 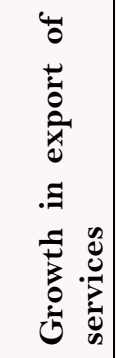 & $\begin{array}{l}\frac{1}{5} \\
0 \\
0 \\
0 \\
0 \\
0 \\
0 \\
0\end{array}$ & 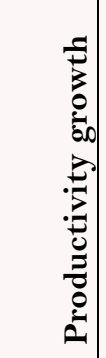 & 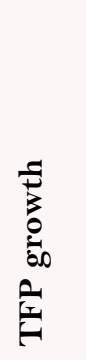 & 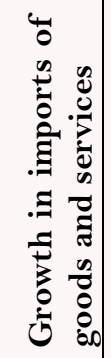 & 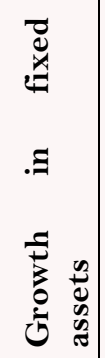 & क्ष \\
\hline Growth in export of goods & 1.00 & & & & & & & \\
\hline Growth in export of services & 0.43 & 1.00 & & & & & & \\
\hline GDP Growth & 0.64 & 0.56 & 1.00 & & & & & \\
\hline Productivity growth & 0.67 & 0.49 & 0.93 & 1.00 & & & & \\
\hline TFP growth & 0.68 & 0.51 & 0.91 & 0.97 & 1.00 & & & \\
\hline Growth in imports of goods and services & 0.84 & 0.65 & 0.76 & 0.70 & 0.71 & 1.00 & & \\
\hline Growth in fixed assets & 0.46 & 0.39 & 0.82 & 0.75 & 0.59 & 0.55 & 1.00 & \\
\hline Employment growth & 0.16 & 0.34 & 0.50 & 0.14 & 0.17 & 0.38 & 0.43 & 1.00 \\
\hline
\end{tabular}

\section{DATA AND METHODOLOGY}

\subsection{Data}

Source of all data used in this study are Eurostat and ILO database (data on country's level). Data have an annual frequency. Variables used in this study are: Gross Domestic product (current prices, million euro), net fixed assets (current prices, million euro), total employment, export of goods, export of services (sectoral approach as defined in section 1) and expenditures for R\&D (current prices, million euro).

In this study, we use data from thirty-eight European countries, from 2000 to 2019.

\subsection{Methodology}

To assess the impact of export growth to GDP growth, we estimated aggregate production function using panel data. We applied panel pooled OLS model with fixed effects.

Following the approach of Herzer et al. (2006); Kalaitzi and Cleeve (2018); Bacovic et al. (2020) and Gabriele (2006) aggregate production is defined as:

$$
Y_{t}=A_{t} K_{t}^{\alpha} L_{t}^{\beta}, 0<\alpha+\beta<1
$$

With $Y_{t}$ representing the total output at the time $t, A_{t}$ is the total factor productivity, and $K_{t}$ and $L_{t}$ represent the capital stock and labour. The constants $\alpha$ and $\beta$ represent the share of capital and labour in income.

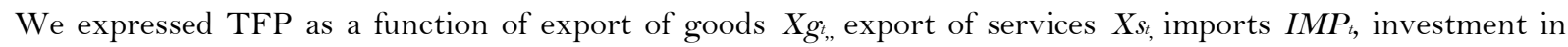
$\mathrm{R} \& \mathrm{D}-R_{t}$, and other exogenous factors $C_{t}$.

$$
A_{t}=f\left(X g_{t}, X s_{t}, I M P_{t}, R_{t}, C_{t}\right)=X g_{t}^{\gamma} X s_{t}^{\delta} I M P_{t}^{\theta} R_{t}^{\theta} C_{t}
$$

A combination of Equation 1 and 2 is:

$$
Y_{t}=C_{t} K_{t}^{\alpha} L_{t}^{\beta} X g_{t}^{\gamma} X s_{t}^{\delta} I M P_{t}^{\theta} R_{t}^{\vartheta}
$$

\footnotetext{
${ }^{9}$ Balance of payments by country - annual data (BPM6) [bop_c6_a], extracted on February 25, 2021
} 
with $\alpha, \beta, \gamma, \delta, \theta$, and $\varphi$ as the elasticities of production with respect to the: $K_{t}, L, X g_{t}, X s_{t}, I M P_{t}$, and $R_{t}$.

Natural logs of Equation 3 is represented as follows:

$$
L Y_{t}=c+\alpha L K_{t}+\delta L L_{t}+\gamma L X g_{t}+\delta L X s_{t}+\theta L I M P_{t}+\vartheta L R_{t}+\varepsilon_{t},
$$

with $c$ is the intercept, $\alpha, \beta, \gamma, \delta$, $\theta$, and $\varphi$ are constant elasticities and $\varepsilon_{t}$ is the error term.

To estimate impact from services exports and goods exports growth to the labour productivity growth, we followed approach of Gabriele (2006) but replaced GDP growth with output per person growth, as follows.

$$
L Y l_{t}=c+\alpha L X g_{t}+\delta L X s_{t}+\varepsilon_{t}
$$

Where $Y l_{t}$ stands for labour productivity (output per person employed), while remaining is same as previously presented.

\subsection{Empirical Results}

The estimated Equation 4 shows that all exogenous variables have significant and positive impact to GDP growth. As we are particularly interested in exports of goods and exports of services, results show that impact from growth in exports of goods by one unit leads to GDP growth by 0.09 units, while growth in exports of services leads to GDP growth by 0.06 units (see Table 5). Impact of growth of import is also strong, confirming results obtained by Chuang (1998) who shows that if capital goods were imported from technologically advanced economies, local productivity will grow. The R\&D also has strong and positive impact on GDP growth.

Table-5. Estimation results (Equation 4)

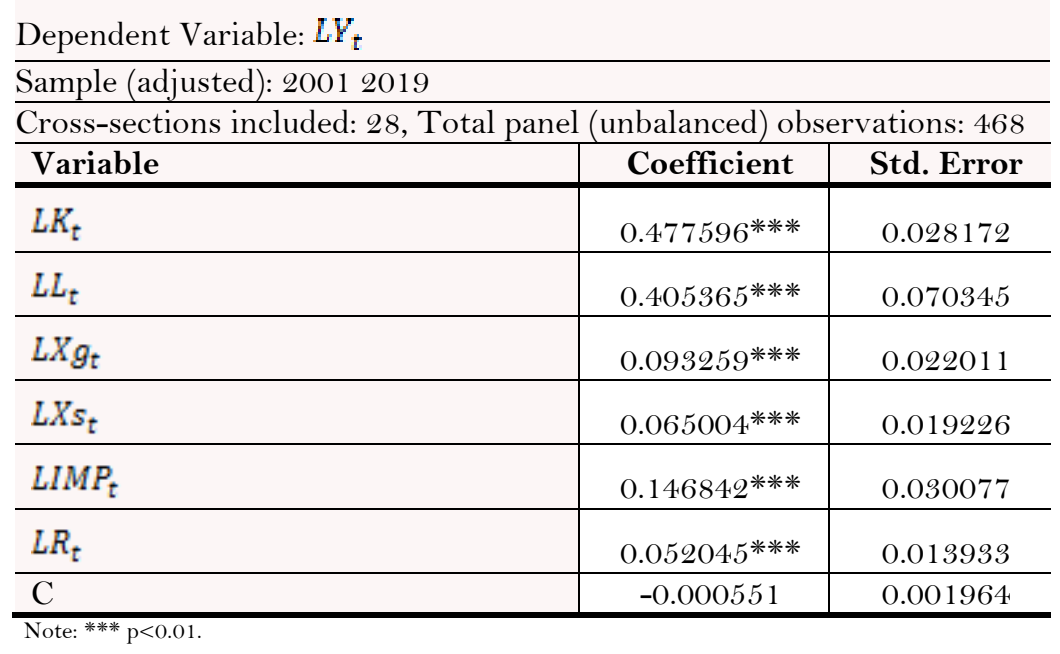

The results in this study corresponds with results of the study UNCTAD/Gabriele (2006); Sandri et al. (2016) and Bacovic et al. (2020).

The estimation results for Equation 5 are presented in Table 6. The estimation results show that all exogenous variables have significant and positive impact to the labour productivity growth, but that impact from growth in exports of goods is higher (Table 6). This is similar to results presented by Moro (2015) who argued that services have diminishing effect on total factor productivity. 


\begin{tabular}{|c|c|c|}
\hline \multicolumn{3}{|c|}{ Sample (adjusted): 20012019} \\
\hline \multicolumn{3}{|c|}{ Cross-sections included: 32, Total panel (unbalanced) observations: 537} \\
\hline Variable & Coefficient & Std. Error \\
\hline$L X_{g_{t}}$ & $0.259253 * * *$ & 0.022601 \\
\hline$L X s_{t}$ & $0.166084^{* * *}$ & 0.022741 \\
\hline $\mathrm{C}$ & $0.010680^{* * * *}$ & 0.002438 \\
\hline
\end{tabular}

\section{DISCUSSION}

World trade is strongly affected by advances in technology in modern era. Developed countries gain from developing advanced technologies and training people to use them, which further has strong impact on international trade (Lindert, 1986). Empirical evidence shows that, although technological advances are findings its role in services sector, its application is higher in goods sector, particularly manufacturing.

The analysis of the world trade by type of goods (merchandise and services) and by country's income level confirms this. High-income countries export half of the total world merchandise export and more than $80 \%$ of total services export Table 7. Its value of exports share in world GDP is also beyond all other country's income groups.

Table-7. Merchandise and service exports by group of countries, 2005 and 2020.

\begin{tabular}{l|c|c|c|c|c|c|c|c}
\hline & \multicolumn{2}{|c|}{$\begin{array}{c}\text { Merchandise } \\
\text { exports, \% of } \\
\text { world }\end{array}$} & \multicolumn{2}{c|}{$\begin{array}{c}\text { Service exports, } \\
\text { \% of world }\end{array}$} & \multicolumn{2}{c|}{$\begin{array}{c}\text { Merchandise } \\
\text { exports, of } \\
\text { world GDP }\end{array}$} & \multicolumn{2}{c}{$\begin{array}{c}\text { Service } \\
\text { exports, \% of } \\
\text { world GDP }\end{array}$} \\
\hline & $\mathbf{2 0 0 5}$ & $\mathbf{2 0 2 0}$ & $\mathbf{2 0 0 5}$ & $\mathbf{2 0 2 0}$ & $\mathbf{2 0 0 5}$ & $\mathbf{2 0 2 0}$ & $\mathbf{2 0 0 5}$ & $\mathbf{2 0 2 0}$ \\
\hline $\begin{array}{l}\text { Low-income } \\
\text { economies }\end{array}$ & $0.01 \%$ & $0.02 \%$ & $0.37 \%$ & $0.37 \%$ & $0.00 \%$ & $0.01 \%$ & $0.02 \%$ & $0.02 \%$ \\
\hline $\begin{array}{l}\text { Middle-income developing } \\
\text { economies }\end{array}$ & $0.48 \%$ & $0.95 \%$ & $5.32 \%$ & $5.61 \%$ & $0.11 \%$ & $0.20 \%$ & $0.30 \%$ & $0.44 \%$ \\
\hline $\begin{array}{l}\text { High-income } \\
\text { economies }\end{array}$ & $11.86 \%$ & $15.95 \%$ & $17.37 \%$ & $17.71 \%$ & $2.60 \%$ & $3.27 \%$ & $0.98 \%$ & $1.20 \%$ \\
\hline $\begin{array}{l}\text { Low-income developing } \\
\text { (World Bank) }\end{array}$ & $0.01 \%$ & $0.02 \%$ & $0.31 \%$ & $0.31 \%$ & $0.00 \%$ & $0.00 \%$ & $0.02 \%$ & $0.02 \%$ \\
\hline $\begin{array}{l}\text { Lower-middle-income } \\
\text { economies (World Bank) }\end{array}$ & $0.36 \%$ & $0.65 \%$ & $4.94 \%$ & $5.32 \%$ & $0.08 \%$ & $0.13 \%$ & $0.28 \%$ & $0.43 \%$ \\
\hline $\begin{array}{l}\text { Upper-middle-income } \\
\text { economies (World Bank) }\end{array}$ & $3.25 \%$ & $6.03 \%$ & $11.38 \%$ & $11.41 \%$ & $0.71 \%$ & $1.24 \%$ & $0.64 \%$ & $0.70 \%$ \\
\hline $\begin{array}{l}\text { High-income } \\
\text { (World Bank) }\end{array}$ & $58.22 \%$ & $45.64 \%$ & $83.37 \%$ & $82.95 \%$ & $12.78 \%$ & $9.37 \%$ & $4.70 \%$ & $4.73 \%$ \\
\hline $\begin{array}{l}\text { High-income OECD members } \\
\text { (World Bank) }\end{array}$ & $46.93 \%$ & $36.26 \%$ & $75.99 \%$ & $75.15 \%$ & $10.30 \%$ & $7.44 \%$ & $4.29 \%$ & $4.14 \%$ \\
\hline $\begin{array}{l}\text { Source: UnCTAD statistics. } \\
\text { https://unctadstat.unctad.org/wds/ReportFolders/reportFolders.aspx?sCs_ChosenLang=en). }\end{array}$ & & & &
\end{tabular}

Services exports' share in total world trade increased from $20.4 \%$ in 2005 to $22.3 \%$ in 2020 , emphasising growing relevance of the services sector not only from output growth but international trade perspective.

Developing countries, especially those with less developed manufacturing sector, often strategize toward services sector to increase its income. It is often the case that those countries prioritise less technologically demanding services sectors, as travel and trade. It is often empirically evidenced that expansion of export of travel leads to improved current account balance, output and employment growth in short run (Bacovic et al., 2020) but does not contribute to the long-term output growth perspectives, due to its lower TFP growth compared to other activities. Several empirical studies confirms that TFP growth, seen often as important determinant of economic 
growth, is lower in services. It has been also shown that in the knowledge-intensive services, TFP growth may even surpass TFP growth in manufacturing (Bacovic., 2021).

Developed countries often have different approach and prioritise toward more technologically and knowledge demanding services sectors, as transport, information and technologies, business services, R\&D activities and others.

\section{CONCLUSION}

The relevance of export of services for GDP and productivity growth was confirmed in several studies, although it is still frequent issue in economic debates how strong its significance is compared to the same in relation to exports of goods. In addition, if a sectoral approach is applied, variations between different types of services in relation to their impact on growth may occur.

In this study, we analyse the impact of exports of services on GDP and productivity growth in a sample of thirty-eight European countries and the period 2000-2019. Descriptive statistics analysis of panel data shows that growth in exports of goods is more positively related to GDP growth, total fixed assets growth, labour productivity and TFP growth, while growth in export of services is more positively related to employment growth. In addition, the analysis shows that the volume of exports (in terms of its share in relation to GDP) of knowledge-intensive services (information and communication, other business services, intellectual property) is higher in more developed countries (measured as GDP per person). The pooled OLS (panel data, fixed effects) model, where GDP growth and labour productivity growth being endogenous shows that growth in exports of services has a positive impact on GDP growth, although the positive impact of growth in exports of goods is higher. It applies to labour productivity growth, with a larger positive impact from exports of goods than services.

This study contributed to the literature as it presents the estimation of the impact of exports of services on GDP and productivity growth using the most recent data for European countries for the last two decades.

It is important to emphasise the fact that export of services does have a positive impact on economic growth, although that impact of export of goods is stronger. The export of services contributes to balance of payments equilibrium, also has positive effects on country's employment, so it is good policy approach to achieve macroeconomic equilibrium.

Further research may be aimed to analyse determinants of services sector growth, as services sector growth may have positive impact to non-services sectors growth, with overall positive contribution to the long-run growth.

Funding: This study received no specific financial support.

Competing Interests: The author declares that there are no conflicts of interests regarding the publication of this paper.

\section{REFERENCES}

Amil, D., Giannoplidis, A., \& Lipp-Lingua, C. (2007). Evolution of high-technology manufacturing and knowledge-intensive services. Luxembourg: Eurostat.

Bacovic, M., Jacimovic, D., \& Cerovic Smolovic, J. (2020). Impact of export of travel services on current account balance and growth in Mediterranean countries. Prague Economic Papers, 29(6), 710-728. Available at: https://doi.org/10.18267/j.pep.748.

Bacovic, M. (202 1). Sectoral approach in output growth decomposition and its determinants in Europe. Management $\S^{2}$ Economics Research Journal, 3(2), 1-21. Available at: https://doi.org/10.48100/merj.202 1.159.

Bacovic, M. (2021). Total factor productivity growth in upper middle-income Balkan countries from 2000-2017, total economy and sectoral approach: Growth accounting method. Economics, 1(46), 79-97. Available at: https://doi.org/10.15611/aoe.2021.1.04.

Barro, J. R. (1998). Macroeconomics (5th ed.). Cambridge, Massachusetts; London, England: The MIT Press. 
Cattaneo, O., Engman, M., Saez , S., \& Stern, R. M. (2010). Assesing the potential of services trade in developing countries: An overview. In O. Cattaneo, M. Engman, S. Saez, \& R. M. Stern, International trade in services: New trends and opportunities for developing countries (pp. 1-29). Washington, D.C: The World Bank.

Chala, V. (2015). The peculiarities of trade specialization in creative industries in the Central and Eastern European countries. Eastern Journal of European Studies, 6(1), 91-109.

Chen, T.-J., \& Tang, D.-P. (1990). Export performance and productivity growth: The case of Taiwan. Economic Development and Cultural Change, 38(3), 577-585. Available at: https://doi.org/10.1086/451816.

Chuang, Y.-c. (1998). Learning by doing, the technology gap, and growth. International Economic Review, 39(3), 697-721. Available at: https://doi.org/10.2307/2527396.

Comin, D. (2010). Total factor productivity. In S. Durlauf, \& L. Blume, Economic Growth (pp. 260-263). London: The New Palgrave Economics Collection, Palgrave Macmillan.

Dincer, N. N., \& Tekin-Koru, A. (2017). Gains from trade due to within-firm productivity: does services exporting matter. Economics: The Open-Access, Open-Assessment E-Journal, 11(1), 1-17. Available at: https://doi.org/10.5018/economicsejournal.ja.2017-11.

Dombi, Á. (2013). Economic growth and development in central and Eastern Europe after the transformation. Public Finance Quarterly, 58(4), 452-468.

Foster-McGregor, N., \& Verspagen, B. (2017). Decomposing total factor productivity growth in manufacturing and services. Asian Development Review, 34(1), 88-115. Available at: https://doi.org/10.1162/adev_a_00082.

Francois, J., \& Hoekman, B. (2010). Services trade and policy. Journal of Economic Literature, 48(3), 642-692.

Gabriele, A. (2006). Exports of services, exports of goods, and economic growth in developing countries. Journal of Economic Integration, 21(2), 294-317. Available at: https://doi.org/10.11130/jei.2006.21.2.294.

Harris, R., \& Moffat, J. (2015). The impact of exporting and importing goods and services on productivity in the UK. The World Economy, 38(11), 1781-1794. Available at: https://doi.org/10.1111/twec.12292.

Herzer, D., Nowak-Lehmann, D. F., \& Siliverstovs, B. (2006). Export-led growth in Chile: Assessing the role of export composition in productivity growth. The Developing Economies, 44(3), 306-328. Available at: https://doi.org/10.1111/j.1746-1049.2006.00019.x.

Kalaitzi, A. S., \& Cleeve, E. (2018). Export-led growth in the UAE: Multivariate causality between primary exports, manufactured exports and economic growth. Eurasian Business Reviere, 8(3), 341-365. Available at: https://doi.org/10.1007/s40821-017-0094-4.

Kordalska, A., \& Olczyk, M. (2018). CEE trade in services: Value-added versus gross terms approaches. Eastern European Economics, 56(4), 269-291. Available at: https://doi.org/10.1080/00128775.2018.1459194.

Krenz, A. (2014). Services sectors concentration and countries specialization patterns in the European Union: A comparative analysis with a special focus on France, Germany, Greece and the UK. Regional and Sectoral Economic Studies, 14(1), 2332.

Lindert, P. H. (1986). International economics, 8e. Illinois: IRWIN.

Malchow-Møller, N., Munch, J. R., \& Skaksen, J. R. (2015). Services trade, goods trade and productivity growth: Evidence from a population of private sector firms. Review of World Economics, 151(2), 197-229. Available at: https://doi.org/10.1007/s 10290-014-0208-3.

Manghnani, R. (2020). Exports and productivity: The role of imported inputs and investment in R\&D. Washington, DC: World Bank, Policy Research Working Paper, No. 9281.

Minondo, A. (2014). The relationship between export status and productivity in services: A firm-level analysis for Spain. Bulletin of Economic Research, 66(S1), S138-S146. Available at: https://doi.org/10.1111/boer.12029.

Mishra, S., Lundstrom, S., \& Anand, R. (2011). Sophistication in service exports and economic growth. The World Bank, Policy Research Working Paper 5606. 
Moro, A. (2015). Structural change, growth, and volatility. American Economic Journal: Macroeconomics, 7(3), 259-294. Available at: https://doi.org/10.1257/mac.20130057.

Nelson, R. R. (2000). The sources of economic growth. Cambridge, Massachusetts/London, England: Harvard University Press.

Pain, N., \& Welsum, v. D. (2005). International production relocation and exports of services. OECD Economic Studies, 2004(1), 67-94. Available at: https://doi.org/10.1787/eco_studies-v2004-art4-en.

Riezman, R., Whiteman, C., \& Summers, P. (1996). The engine of growth or its handmaiden? A time-series assessment of export-led growth. Empirical Economics, 21(1), 77-110. Available at: https://doi.org/10.1007/bfo 1205495 .

Sandri, S., Alshyab, N., \& Ghazo, A. (2016). Trade in goods and services and its effect on economic growth-the case of Jordan. Applied Econometrics and International Development, 16(2), 113-128.

Schwarzer, J. (2017). The effects of exporting on labor productivity: Evidence from German firms. Council on Economic Policies; Working Papers No. 1702.

Sorbe, S., Gal, P., \& Millot, V. (2018). Can productivity still grow in service-based economies? Literature overview and preliminary evidence from OECD countries. OECD, Working Papers No. 79.

Views and opinions expressed in this article are the views and opinions of the author(s), Asian Development Policy Review shall not be responsible or answerable for any loss, damage or liability etc. caused in relation to/arising out of the use of the content. 